\title{
Comparison of the accommodative effects of Carbachol and Pilocarpine with reference to accommodative esotropia
}

\author{
H. P. WILLIAMS
}

Moorfields Eye Hospital, City Rd, London

The use of miotic drops in the treatment of accommodative strabismus is widely accepted, when there is present a higher than normal accommodative convergence/accommodation (AC/A) ratio. According to their pharmacological action, the miotics in current use fall into two groups - the anticholinesterases and the parasympathomimetics. Pilocarpine and Carbachol belong to the latter group, and while the value of Pilocarpine in accommodative esotropia is accepted, the value or otherwise of Carbachol appears to be unknown. This paper describes an experiment in which the cyclotonic effects of Pilocarpine and Carbachol are compared.

Accommodation is simultaneously associated with convergence in order to maintain binocular single vision. The AC/A ratio expresses the degree of accommodative convergence, in prism dioptres, which occurs for a given amount of accommodation, measured in dioptres. The stimulus for accommodation has its origin in the central nervous system and is effected through the parasympathetic outflow to the ciliary muscle. In the presence of an abnormal AC/A ratio, excess convergence takes place for near, and if this escapes fusional control, it will result in esotropia. The mechanism by which miotics decrease the AC/A ratio lies not in miosis but in the peripheral stimulation of the ciliary muscle, thus lessening the amount of central innervational stimulus required and so reducing the accommodative response and convergence.

Although miotic therapy for strabismus was described a century ago, it was not widely used until the work of Abraham (1949) was published. In the anti-cholinesterase group of drugs, Echothiophate (Phospholine) iodide and Isofluorophate (DFP) were favoured for their prolonged effects. Doubts were raised concerning the safety of these drugs when sideeffects, including iris cysts, lens opacities, irreversible miosis, angle-closure glaucoma, retinal detachment, and scoline apnoea in general anaesthesia, were reported (Pantuck, ig66; Goldstein, 1968; Roy, Hanna, Brown, and Clifton, 1970). Pilocarpine and Carbachol act directly upon the parasympathetic effector cell, but Carbachol also resists hydrolysis by acetylcholinesterase and might be thought to provide a longer acting and useful alternative to Pilocarpine in the treatment of accommodative esotropia.

\section{Materials used}

Pilocarpine nitrate eyedrops were used in I, 2, and 4 per cent. solutions. These were dispensed by Moorfields Eye Hospital for routine use at the Institute of Ophthalmology, as were the Carbachol drops, used in $0.75,1.5$, and 3 per cent. solutions, with o.or per cent. Benzalkonium chloride added 
only as an antibacterial preservative. Carbachol in $\mathrm{I} \cdot 5$ per cent. solution was made up separately with the addition of either 0.03 per cent. Benzalkonium chloride or Brij $_{35}$ to act as a wetting agent. Brij ${ }_{35}$ is a commercial non-ionic detergent which has been used experimentally as a wetting agent (Marsh and Maurice, I97 I). Isoptocarbachol is a proprietary preparation of Carbachol containing hydroxypropyl methylcellulose (4000 cps) I per cent. to lower surface tension, and it was used in strengths of 0.75 , $\mathrm{I} \cdot 5$, and 3 per cent. Carbachol $\mathrm{I} \cdot 5$ per cent was also dispensed in a petrolatum base ointment for use in the experiment (Table I). The $\mathrm{pH}$ of each preparation is shown in Table II.

\section{Table I}

\section{Drug preparation}

Isoptocarbachol $0 \cdot 75 ; 1 \cdot 5 ; 3$ per cent. Carbachol $1 \cdot 5$ per cent.

Carbachol $1 \cdot 5$ per cent.

Carbachol $\mathrm{I} \cdot 5$ per cent.

Carbachol $0.75 ; 1.5 ; 3$ per cent.

Pilocarpine nitrate I; 2; 4 per cent.
Wetting agent or vehicle

Hydroxypropyl methylcellulose i per cent.

Benzalkonium chloride 0.03 per cent.

Brij $_{35}$

Petrolatum base ointment

None

None

\section{Table II}

\begin{tabular}{lc}
\hline Drug preparation & $p H$ \\
\hline Isoptocarbachol & $6 \cdot 2$ \\
Carbachol/Benzalkonium chloride 0.03 per cent. & $4 \cdot 4$ \\
Carbachol/Benzalkonium chloride 0.0 I per cent. & $4 \cdot 6$ \\
Carbachol/Brij ${ }_{35}$ & $7 \cdot 4$ \\
Carbachol ointment & $4 \cdot 4$ \\
Pilocarpine nitrate & $4 \cdot 4$ \\
\hline
\end{tabular}

\section{Method of study}

The relative amplitude of binocular accommodation for the observer (HPW), was found by placing convex lenses before both eyes simultaneously, and increasing the power of the lenses until the $\mathrm{N}_{5}$ line of print, set $20 \mathrm{~cm}$. from the eyes, just became blurred. This was repeated using concave lenses of increasing power. The values found were ${ }_{5} \mathrm{D}$ of accommodation and ${ }_{3} \mathrm{D}$ of relaxation of accommodation. This procedure was repeated at various times of day for several days and the relative amplitude of binocular accommodation, $8 \mathrm{D}$, is in accord with the normal mean values for age $(3 \mathrm{I})$ and sex (male) given by Duane (1922).

An R.A.F. near-point gauge was mounted on a stand so that the Snellen $\mathrm{N}_{5}$ line was $20 \mathrm{~cm}$. from the observer. A Skeoch trial frame was used with a $-I \cdot 5 D$ sph correction for the right eye which made the observer emmetropic and orthophoric. I drop, or $1 \mathrm{~cm}$. of ointment, of the drug being tested was placed in each lower fornix by an assistant. The eyes were not massaged or rubbed. Concave lenses of equal power were then inserted simultaneously in the trial frame for no more than 5 sec., and the clarity of print noted. The lens powers were increased until the $\mathrm{N}_{5}$ line became just focused. After instillation of the drug, readings were taken at 10-min. intervals for the first hour, as most cyclotonia occurred within this period, and were repeated $30 \mathrm{~min}$. later and at hourly intervals for up to $6 \mathrm{hrs}$. The cyclotonic action of each drug was measured by the power of the concave lens which neutralized the induced myopia. The increase in accommodation, $\delta \mathrm{A}$, is found from the expression

$$
\mathrm{A}_{\text {(cyc) }}-\mathrm{A}_{(0)}=\delta \mathrm{A} \text {, }
$$

where $A_{(c y c)}$ equals the increased accommodative power resulting from the effect of the drug and 
$A_{(0)}$ is the original accommodation exerted in the system described before the introduction of the drug $\left({ }_{5} \mathrm{D}\right) . \delta \mathrm{A}$ was plotted against time in a strength-duration curve; values for $\delta \mathrm{A}$ are given in Table III. Maximum miosis was achieved when using either 3 per cent. Carbachol or 4 per cent. Pilocarpine and the pupil diameters were measured at this time with the Haag-Streit variable slitbeam and a blue filter.

Table III Values for $\delta A$

\begin{tabular}{|c|c|c|c|c|c|c|c|c|c|c|c|c|}
\hline \multirow{2}{*}{ Drug used } & \multicolumn{12}{|c|}{ Time (min.) } \\
\hline & 10 & 20 & 30 & 40 & 50 & 60 & 90 & 120 & 180 & 240 & 300 & 360 \\
\hline $\begin{aligned} \text { Pilocarpine } 1 \text { per cent. } \\
2 \text { per cent. } \\
4 \text { per cent. }\end{aligned}$ & $\begin{array}{l}3 \cdot 5 \\
3 \cdot 5 \\
4\end{array}$ & $\begin{array}{l}4 \cdot 5 \\
5 \\
5 \cdot 5\end{array}$ & $\begin{array}{l}5 \\
6 \\
6\end{array}$ & $\begin{array}{l}5 \cdot 5 \\
6 \\
6\end{array}$ & $\begin{array}{l}5 \cdot 5 \\
6 \\
5 \cdot 5\end{array}$ & $\begin{array}{l}5 \\
5 \cdot 5 \\
5\end{array}$ & $\begin{array}{l}4 \\
4 \cdot 5 \\
4 \cdot 5\end{array}$ & $\begin{array}{l}3 \cdot 5 \\
4 \\
4\end{array}$ & $\begin{array}{l}3 \cdot 5 \\
4 \\
4\end{array}$ & $\begin{array}{l}3 \\
4 \\
3 \cdot 5\end{array}$ & $\begin{array}{l}3 \\
4 \\
3 \cdot 5\end{array}$ & $\begin{array}{l}3 \cdot 5 \\
3\end{array}$ \\
\hline $\begin{array}{r}\text { Carbachol } 0.75 \text { per cent. } \\
1.5 \text { per cent. } \\
3 \text { per cent. }\end{array}$ & $\begin{array}{l}\overline{3 \cdot 5} \\
3 \cdot 5 \\
3 \cdot 5\end{array}$ & $\begin{array}{l}\overline{4} \\
4 \cdot 5 \\
3 \cdot 5\end{array}$ & $\begin{array}{l}\overline{4 \cdot 5} \\
4 \cdot 5 \\
4\end{array}$ & $\begin{array}{l}4 \\
4 \\
4\end{array}$ & $\begin{array}{l}\overline{3 \cdot 5} \\
4 \\
3 \cdot 5\end{array}$ & $\begin{array}{l}\overline{3 \cdot 5} \\
4 \\
3 \cdot 5\end{array}$ & $\begin{array}{l}3 \cdot 5 \\
3 \cdot 5 \\
3 \cdot 5 \\
\end{array}$ & $\begin{array}{l}3 \cdot 5 \\
3 \cdot 5 \\
3 \cdot 5 \\
\end{array}$ & $\begin{array}{l}3 \cdot 5 \\
3 \cdot 5 \\
3 \cdot 5 \\
\end{array}$ & $\begin{array}{l}\overline{3 \cdot 5} \\
3 \\
3 \cdot 5 \\
\end{array}$ & $\begin{array}{l}3 \cdot 5 \\
3 \cdot 5 \\
\end{array}$ & $\begin{array}{l}\overline{3 \cdot 5} \\
3\end{array}$ \\
\hline $\begin{array}{r}\text { Carbachol } 1.5 \text { per cent. } \\
\text { Benzalkonium chloride } \\
0.03 \text { per cent. }\end{array}$ & $3 \cdot 5$ & $4 \cdot 5$ & $5 \cdot 5$ & $5 \cdot 5$ & $4 \cdot 5$ & $4 \cdot 5$ & 4 & $3 \cdot 5$ & $3 \cdot 5$ & $3 \cdot 5$ & $3 \cdot 5$ & 3 \\
\hline $\begin{array}{l}1.5 \text { per cent. Carbachol } \\
\text { ointment }\end{array}$ & 4 & 5 & 5 & 5 & 5 & $4 \cdot 5$ & $4 \cdot 5$ & 4 & 4 & 4 & $3 \cdot 5$ & $3 \cdot 5$ \\
\hline $\begin{array}{r}\text { Isoptocarbachol } 0.75 \text { per cent. } \\
1.5 \text { per cent. } \\
3 \text { per cent. }\end{array}$ & $\begin{array}{l}\overline{3 \cdot 5} \\
3 \cdot 5 \\
4 \cdot 5 \\
\end{array}$ & $\begin{array}{l}\overline{4} \\
4 \cdot 5 \\
5\end{array}$ & $\begin{array}{l}4 \\
5 \\
5\end{array}$ & $\begin{array}{l}\overline{3 \cdot 5} \\
4 \cdot 5 \\
4 \cdot 5 \\
\end{array}$ & $\begin{array}{l}\overline{3 \cdot 5} \\
4 \cdot 5 \\
4 \cdot 5 \\
\end{array}$ & $\begin{array}{l}\overline{3 \cdot 5} \\
3 \cdot 5\end{array}$ & $\begin{array}{l}\overline{3 \cdot 5} \\
4 \\
3 \cdot 5\end{array}$ & $\begin{array}{l}\overline{3 \cdot 5} \\
3 \cdot 5 \\
3 \cdot 5 \\
\end{array}$ & $\begin{array}{l}\overline{3 \cdot 5} \\
3 \cdot 5 \\
3 \cdot 5 \\
\end{array}$ & $\begin{array}{l}\overline{3 \cdot 5} \\
3 \cdot 5 \\
3 \cdot 5 \\
\end{array}$ & $\begin{array}{l}\mathbf{3 \cdot 5} \\
3 \cdot 5 \\
3 \\
\end{array}$ & $\begin{array}{l}\overline{3 \cdot 5} \\
3 \\
3 \\
\end{array}$ \\
\hline $\begin{array}{l}1.5 \text { per cent. Carbachol/Brij } 35 \\
\text { Right eye } \\
\text { Left eye }\end{array}$ & $\begin{array}{l}4 \\
3 \cdot 5\end{array}$ & $\begin{array}{l}4 \cdot 5 \\
3 \cdot 5\end{array}$ & $\begin{array}{l}\mathbf{5} \\
\mathbf{3}\end{array}$ & $\begin{array}{l}4 \cdot 5 \\
3\end{array}$ & $\begin{array}{l}4 \cdot 5 \\
3\end{array}$ & $\begin{array}{l}4 \\
3\end{array}$ & $\begin{array}{l}3 \cdot 5 \\
3\end{array}$ & $\begin{array}{l}3 \cdot 5 \\
3\end{array}$ & $\begin{array}{l}3 \\
3\end{array}$ & $\begin{array}{l}3 \\
3\end{array}$ & & \\
\hline
\end{tabular}

\section{Results}

Figs I and 2 demonstrate clearly the greater effects of Pilocarpine 4 and I per cent. in comparison with Carbachol 3 and 0.75 per cent. respectively, when the latter drug contained no wetting agent; 40 min. after instillation, the amount of accommodation induced by Pilocarpine 4 per cent. is $2 \mathrm{D}$ greater than that by Carbachol 3 per cent., as is that induced by Pilocarpine I per cent. when compared with Carbachol 0.75 per cent. 50 min. after instillation. The duration of action of Pilocarpine is also longer than that of Carbachol.

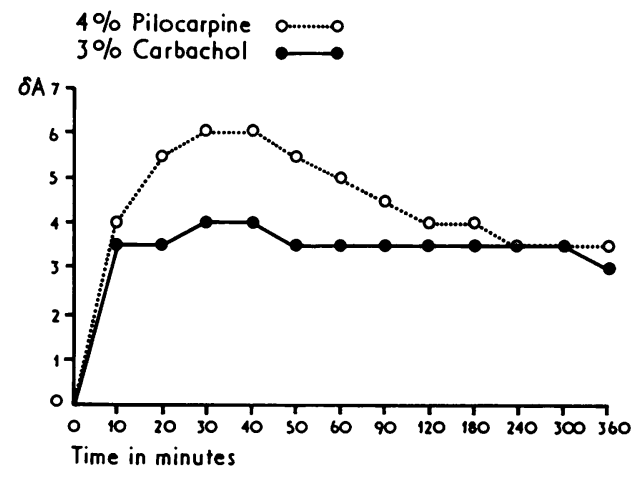

FI G. I Strength duration curves of Pilocarpine and Carbachol

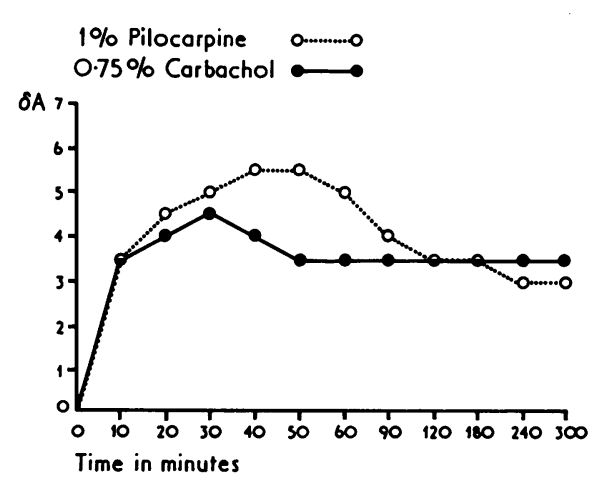

FI G. 2 Strength duration curves of Pilocarpine and Carbachol

Figs 3 and 4 show the strength duration curves of Pilocarpine 2 per cent. and Carbachol I. 5 per cent., when the latter is used in ointment form or with one of the above mentioned wetting agents. 

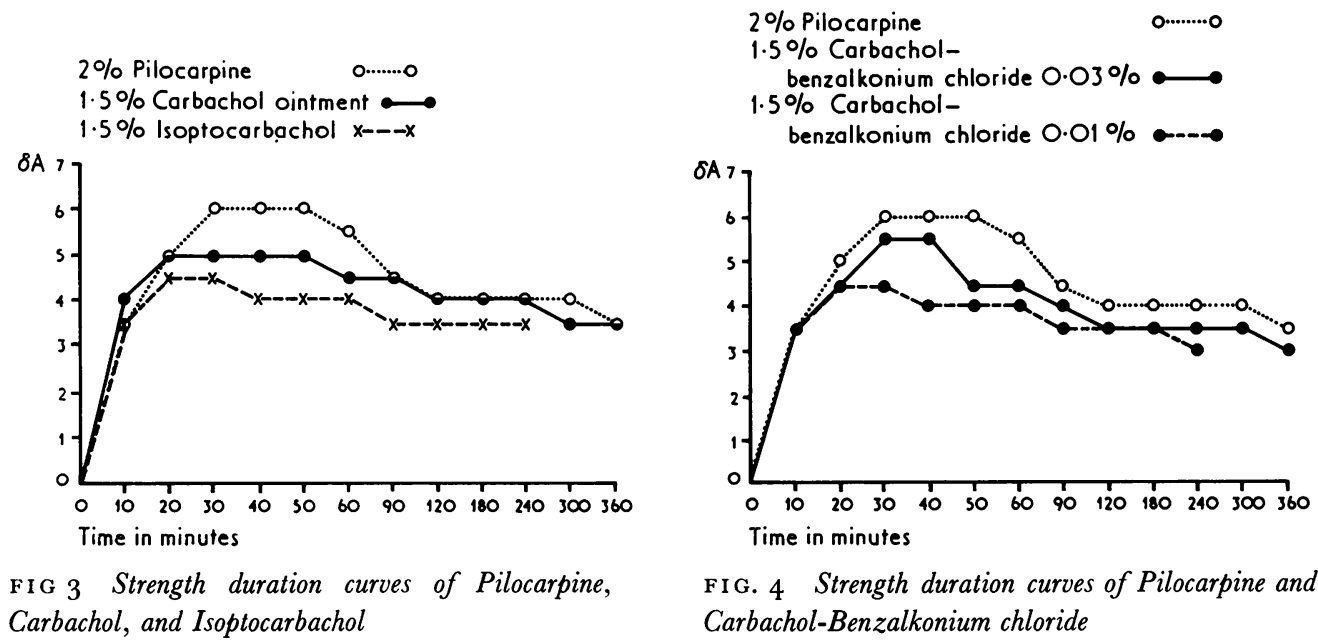

FIG. 4 Strength duration curves of Pilocarpine and Carbachol-Benzalkonium chloride

Fig. 5 shows that Carbachol with Brij ${ }_{35}$ produced the most rapid onset of cyclospasm but the effect was small and of short duration and the degree of cyclospasm was greater in the right eye than in the left. The maximum increase in accommodation was achieved using Carbachol with 0.03 per cent. Benzalkonium chloride and the longest lasting effect by using the drug in ointment form.

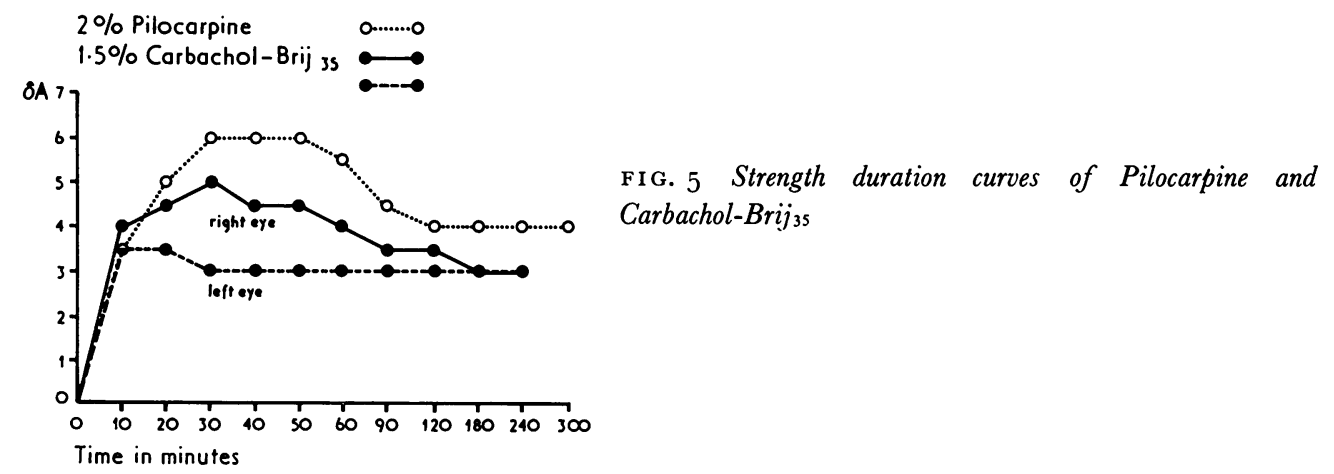

However, in an overall comparison, Pilocarpine 2 per cent. caused a greater increase in accommodation and a longer duration of action than Carbachol $\mathrm{I} \cdot 5$ per cent. employing any of the wetting agents or vehicles. The maximum miosis with Pilocarpine 4 per cent. was $2 \mathrm{~mm}$. and with Carbachol 3 per cent. it was $3 \mathrm{~mm}$.

\section{Comment}

The therapeutic value of Carbachol has been well documented and emphasizes the properties of miosis and the lowering of intraocular pressure, as interest in this drug was related to the treatment of chronic open-angle glaucoma and stimulation of the ciliary muscle was referred to only as a side-effect (O'Brien and Swan, 1942). Carbachol, which is formed by substituting a terminal amino group in the acetylcholine molecule, is a quaternary ammonium compound, and so has the pharmacological characteristics of being lipid insoluble, 
surface inactive, and hydrophilic. Carbachol, therefore, penetrates the cornea very poorly, whereas Pilocarpine, which, being an alkaloid and possessing biphasic solubility, penetrates the cornea readily. Carbachol exerts its parasympathomimetic effects not only by acting upon the effector cell, but also indirectly by resisting hydrolysis by cholinesterase. It has been suggested by Wurzel (1967) that this could occur if Carbachol combined with the enzyme in the manner of an anticholinesterase. Corneal penetration by Carbachol may be enhanced practically, either by reducing the surface tension using Benzalkonium chloride as a wetting agent (O'Brien and Swan, I942) or by administering it in a petrolatum-based ointment and massaging the cornea through closed lids (Swan, 1943). Carbachol in ointment form or in a methylcellulose vehicle will have a prolonged corneal contact time and this may also help penetration. Trauma to the epithelium is known to promote the entry of Carbachol into the eye and, since any concentration of Benzalkonium chloride greater than $0^{\circ} 03$ per cent. has been found to cause epithelial damage (O'Brien and Swan, 1942), this was the maximum strength that could be used in the drops. No epithelial lesions were found in this experiment.

The effectivity of the wetting agents and vehicles used could be compared indirectly by the rate of onset of cyclospasm. The rapid rate of onset using Brij ${ }_{35}$ was followed by a rapid decline in induced accommodation and is interesting when compared with the ocular hypotensive action of Carbachol which may last many hours, and when the pharmacological resistance to cholinesterase is recalled. The prolonged effect of Carbachol ointment may depend in part on its not being as easily lost in tear drainage as when used in drop form. Constriction of the pupil increases depth of focus and this in turn influences the stimulus to accommodate. The maximum miosis found with Carbachol and Pilocarpine was respectively $3 \mathrm{~mm}$. and $2 \mathrm{~mm}$. and therefore, in so far as this particular experiment is concerned, Carbachol is at a disadvantage in comparison with Pilocarpine in improving the depth of focus.

Considering the mechanism of action of miotics in the treatment of accommodative esotropia, Breinin (197I) states that, experimentally, the anticholinesterases facilitate accommodation by potentiating neuromuscular transmission in the ciliary body synapses. He adds that these drugs cause no significant change in the refractive state of the eye, unlike the direct-acting parasympathomimetic agents, including Carbachol and Pilocarpine, which do cause spasm of accommodation. Ripps, Chin, Siegel, and Breinin (1962) stated that miosis and increased depth of focus played no significant part in altering the $\mathrm{AC} / \mathrm{A}$ ratio; indeed, many clinicians use a cyclotonic-mydriatic combination in treatment to avoid the formation of iris cysts.

The side-effects of Pilocarpine and Carbachol in this experiment included mild stinging and lacrimation lasting less than $30 \mathrm{sec}$, and conjunctival injection which remained noticeable for as long as $2 \mathrm{hrs}$ depending on the strength of the drops used. Both drugs caused a vague sensation of intraocular pulling and sometimes, when used in their maximum concentrations, a mild frontal headache. Pilocarpine 4 per cent. produced on one occasion bilateral simultaneous accommodative phosphenes which were apparent with even minimal eye movements. The ocular irritation these drops produced could lessen their effectiveness in penetrating the cornea through their being diluted in and lost with the tear flow. It is this fact which must account for the unequal response of the eyes to Carbachol $\mathrm{I} \cdot 5$ per cent-Brij ${ }_{35}$, and marks the unreliability of action of the drug even when carefully instilled. Ocular discomfort occurs if the $\mathrm{pH}$ of drops lies beyond 6.6 or $8 \cdot 7$ (Martin and Mims, I950), and surprisingly when the $\mathrm{pH}$ of each stock solution used in the experiment was measured in a $\mathrm{pH}$ meter, in each case it lay outside the range of ocular 
tolerance (Table II). Carbachol I.5 per cent.-Brij ${ }_{35}$ even when it had been buffered to a $\mathrm{pH}$ of $7 \cdot 4$, still caused some slight ocular irritation.

In conclusion, it may be said that, even if the problem of corneal penetration can be overcome, the rate of onset and duration of cyclospasm with Carbachol is erratic. The results of this experiment point conclusively to the fact that Pilocarpine has a faster acting and longer lasting effect than Carbachol, and that Carbachol is not a drug to consider adding to the miotics already in use in accommodative esotropia.

\section{Summary}

An experiment is described which compares the cyclotonic effects of Pilocarpine and Carbachol. The corneal penetration of Carbachol was enhanced by the addition of various wetting agents, but the irregular onset and short action of Carbachol indicates that it is not a suitable drug for use in accommodative esotropia.

I should like to express my gratitude to Mr. R. F. Fisher and Prof. E. S. Perkins for their advice and encouragement. Alcon Universal Ltd. kindly supplied the Isoptocarbachol drops.

\section{References}

abraham, s. v. (1949) Amer. F. Ophthal., 32, 233

BREININ, G. M. (I97I) Ibid., 7I, 303

DUANe, A. (1922) Trans. Amer. ophthal. Soc., 20, 132

GOLDStein, J. H. (1968) Surv. Ophthal., 13, 31

MARSh, R. J., and MAURICE, D. M. (197I) Exp. Eye Res., II, 43

MARTIN, F. N., and Mims, J. L. (1950) Arch. Ophthal. (Chicago), 44, 561

O'BRIEN, C. S., and SWAN, K. C. (I942) Ibid., 27, 253

Pantuck, E. J. (1966) Brit. F. Anaesth., 38, 406

RIPPS, H., CHIN, N. B., SIEGEL, I. M., and BREININ, G. M. (1962) Invest. Ophthal., I, I 27

ROY, F. H., HANNA, G., BROWN, L. E., and Clifton, E. C. (1970) 7 . pediat. Ophthal., 7, 46

sWAN, K. C. (1943) Arch. Ophthal. (Chicago), 30, 591

wUrzel, M. (1967) Ann. N.Y. Acad. Sci., 144, 694 